\title{
KAJIAN POTENSI WILAYAH PERIKANAN \\ DENGAN PENDEKATAN PRA DI KECAMATAN JUNJUANG SIRIH KABUPATEN SOLOK PROVINSI SUMATERA BARAT
}

\section{ASSESSMENT OF FISHERIES AREA POTENTIAL WITH A PRA APPROACH IN JUNJUANG SIRIH SUBDISTRICT SOLOK DISTRICT, WEST SUMATRA PROVINCE}

\author{
Sarifah Aini ${ }^{1}$, Tatty Yuniarti ${ }^{1}$, Abdul Hanan ${ }^{1}$, Angkasa Putra ${ }^{1,2,3}$, Eli Nurlaela ${ }^{1}$, \\ Hamdani ${ }^{4}$, Dinno Sudino ${ }^{5}$ \\ ${ }^{1}$ Politeknik Ahli Usaha Perikanan, \\ JI. AUP Pasar Minggu-Jakarta Selatan 12520 \\ ${ }^{2}$ Institute of Productivity, Research, Innovation, and Development for Fisheries, \\ Jl. AUP Pasar Minggu-Jakarta Selatan 12520 \\ ${ }^{3}$ Indonesian Maritime Youths, Jl. Raya Casablanca Tebet-Jakarta Selatan 12870 \\ ${ }^{4}$ Politeknik Kelautan dan Perikanan Pariaman \\ JI. Padang Birik-Birik, Pariaman Utara, Kota Pariaman, Sumatera Barat 25562 \\ ${ }^{5}$ Politeknik Kelautan dan Perikanan Pangandaran \\ Jl. Babakan, Kec. Pangandaran, Kab. Pangandaran, Jawa Barat 46396
}

\begin{abstract}
`Email: ainisarifah1606@gmail.com, tatty.yuni@gmail.com, abdulhanan278@gmail.com, angkasaputra80@gmail.com, elimumtaza@gmail.com, hamdanikkp@gmail.com, 16.dinno@gmail.com
\end{abstract}

\begin{abstract}
ABSTRAK
Kabupaten Solok memiliki potensi perikanan yang mumpuni dalam bidang penangkapan, budidaya dan pengolahan. Potensi perikanan dapat dikembangkan dengan cara meningkatkan peranan sumber daya manusia yang menjadi motor penggerak bagi aspek perikanan. Tujuan penelitian untuk mengidentifikasi potensi perikanan dan permasalahannya di Kecamatan Junjuang Sirih. Hasil identifikasi wilayah perikanan diharapkan dapat bermanfaat dijadikan acuan dalam menentukan kegiatan penyuluhan melalui aksi penyuluhan yang tepat. Penelitian dilaksanakan pada tanggal 1 sampai dengan 30 Oktober 2019. Metode penelitian menggunakan Participatory Rural Appraisal (PRA) yang melibatkan masyarakat dalam merumuskan permasalahan. Penentuan jumlah responden diperoleh dengan metode Snowball. Didapatkan 15 responden. Analisis data menggunakan analisis deskriptif kualitatif. Analisis permasalahan perikanan menggunakan metoda tree analisis. Hasil penelitian menunjukkan potensi perikanan meliputi SDA berupa danau, kolam dan sawah minapadi. Sumber daya manausia perikanan meliputi pelaku usaha atau RTP sebanyak 194 orang yang tergabung dalam 14 kelompok perikanan. Bidang usaha kelompok perikanan meliputi penangkapan (80 orang), budidaya (63) dan pengolahan (51). Komoditas unggulan bidang penangkapan adalah ikan billih endemik. Poklahsar mengolah hasil penangkapan menjadi olahan ikan bilih goreng. Komoditas budidaya adalah ikan nila dan ikan lele. Nilai R/C usaha rata-rata di atas 1. SDM yang memiliki usaha penangkapan sebanyak 70 orang. Bidang Budidaya Perikanan dengan potensi pembesaran ikan nila dan lele, Hasil analisis permasalah penangkapan yaitu belum menggunakan alat tangkap ramah lingkungan. Permasalahan budidaya yaitu belum menerapkan CBIB dan harga pakan komersial yang mahal. Bidang pengolahan belum menerapkan sanitasi dan higenitas. Rekomendasi penelitian adalah perlunya penggunaan alat tangkap ramah lingkungan, membuat pakan alternative pengganti pakan komersial dan peningkatan sanitasi higienis.
\end{abstract}

Kata kunci: Potensi, Penangkapan, Budidaya, Pengolahan, Kelayakan usaha.

\section{ABSTRACK}

Solok Regency has excellent fisheries potential in the fields of catching, aquaculture and processing. Fishery potential can be developed by increasing the role of human resources who become the driving force for the fisheries aspect. The purpose of this research is to identify fishery potential and its problems in Junjuang Sirih District. The results of the identification of fishery areas are expected to be useful as a reference in determining extension activities through appropriate extension actions. The research was carried out from 1 to 30 October 2019. The research method used Participatory Rural Appraisal (PRA) which involved the community in formulating problems. Determination of the number of respondents obtained by the Snowball 
method. Obtained 15 respondents. Data analysis used descriptive qualitative analysis. Analysis of fishery problems using the tree analysis method. The results of the study show that fishery potential includes natural resources in the form of lakes, ponds and rice fields. Fishery human resources include business actors or RTP as many as 194 people who are members of 14 fishery groups. The fishery group's business fields include catching (80 people), cultivation (63) and processing (51). The leading commodity in the field of fishing is endemic billih fish. Poklahsar processes the catch into fried bilih fish. Cultivated commodities are tilapia and catfish. The average business $R / C$ value is above 1 . There are 70 human resources who have a fishing business. Fisheries Cultivation Sector with the potential for enlargement of tilapia and catfish. The results of the analysis of fishing problems are that they have not used environmentally friendly fishing gear. The problems of cultivation are that they have not implemented CBIB and the price of commercial feed is expensive. The processing sector has not implemented sanitation and hygiene. Research recommendations are the need to use environmentally friendly fishing gear, make alternative feeds to replace commercial feed and improve hygienic sanitation.

Keywords: Potential Identification, Catching, Cultivation, Processing, Business Feasibility.

\section{PENDAHULUAN}

\section{Latar Belakang}

Indonesia merupakan negara maritim, memiliki wilayah yang dominan luas lautan dari pada daratan. Jika dilihat dari dominasi wilayah yang ada pada Indonesia yaitu lautan itu menunjukan bahwa Indonesia memiliki Potensi yang sangat besar di sektor kelautan dan perikanan yang dapat dikembangkan. Indonesia dianugerahi laut yang begitu luas dengan berbagai sumber daya ikan di dalamnya disamping itu Indonesia adalah negara kepulauan terbesar di dunia karena memiliki luas laut dan jumlah pulau yang besar. Panjang pantai Indonesia mencapai $104.000 \mathrm{~km}$ dengan luas wilayah laut 5,4 juta $\mathrm{Km}^{2}$, mendominasi total luas teritorial Indonesia sebesar 7,1 juta $\mathrm{Km}^{2}$. Potensi tersebut menempatkan Indonesia sebagai negara yang dikaruniai sumber daya kelautan yang besar termasuk kekayaan keanekaragaman hayati dan non hayati kelautan terbesar (Primyastanto \& Pito, 2011). Perairan danau mempunyai potensi perikanan yang cukup tinggi. Perikanan danau mempunyai keanekaragaman ikan yang relatif lebih sedikit dibandingkan dengan perairan laut. Danau Singkarak merupakan danau terbesar kedua di Pulau Sumatera setelah Danau Toba (Syandri, 2008), dan menjadi danau terbesar di Provinsi Sumatera Barat (Wendri, dkk 2019). Danau Singkarak memiliki luas 10.908 ha (Suryono, dkk 2006) dengan kedalaman rata-rata $268 \mathrm{~m}$ (Purnomo, 2006). Danau Singkarak terletak di dua kabupaten, yaitu Kabupaten Solok dan Kabupaten Tanah Datar (Gunarto, 2009 \& Lubis, dkk 2012).

Di Kabupaten Solok memiliki potensi perikanan yang mumpuni dalam bidang penangkapan, budidaya dan pengolahan. Untuk memanfaatkan potensi perikanan tersebut diperlukan pengembangan potensi Sumber Daya Manusia (SDM) yang menjadi motor penggerak bagi aspek perikanan. SDM yang kuat dan berkualitas juga akan memberikan peran utama dalam melakukan usaha perikanan agar mampu berorientasi pada kesejahteraan, pembangunan nasional dan bersaing dalam peningkatan produksi. Wilayah Kecamatan Junjuang Sirih merupakan salah satu Kecamatan di Kabupaten Solok yang terletak pada $00^{\circ} 36^{\prime} 25^{\prime \prime}$ dan $00^{\circ} 49^{\prime} 13^{\prime \prime}$ Lintang Selatan dan $100^{\circ} 27^{\prime} 05^{\prime \prime}$ dan $100^{\circ} 47^{\prime} 21^{\prime \prime}$ Bujur Timur dengan hamparan wilayah yang landai dengan luas wilayah 295,50 $\mathrm{Km}^{2}$, dan dihuni sekitar 31767 jiwa penduduk (Amra, 2019). Identifikasi potensi perikanan dilakukan di Kecamatan Junjuang Sirih dan pengembangan Sumberdaya Manusia dengan melihat status gizi yang dimulai dari anak-anak.

Pelaksanaan Penelitian ini akan dilakukan identifikasi wilayah guna mengetahui keadaan sumber daya manusia, sumber daya alam dan sumber daya penunjang terutama pada wilayah pedesaan. Proses identifikasi wilayah perikanan ini sebagai bahan yang dapat dijadikan acuan dalam menentukan kegiatan penyuluhan melalui aksi penyuluhan yang tepat, untuk memperoleh data dan melibatkan masyarakat pelaku utama periakanan dalam proses dan kegiatan program di Kecamatan Junjuang Sirih dengan menggunakan Participatory Rural Appraisal (PRA). Kegiatan identifikasi perlu dilakukan untuk pengumpulan data, baik data aktual maupun potensial yang 
Available online di: http://ejournal-balitbang.kkp.go.id/index.php/JSJ/index

kemudian di analisis untuk mengetahui masalah yang dihadapi masyarakat Kecamatan Junjuang Sirih Kabupaten Solok Sumatera Barat untuk merumuskan tujuan serta cara mencapai tujuan.

\section{Tujuan}

Tujuan dari Penelitian adalah sebagai berikut:

1. Mengumpulkan data, mengolah, dan menyusun data potensi perikanan di Kecamatan Junjuang Sirih Kabupaten Solok Provinsi Sumatera Barat.

2. Mengumpulkan, mengolah, dan menganalisis permasalahan perikanan yang berada di Kecamatan Junjuang Sirih Kabupaten Solok Provinsi Sumatera Barat.

3. Menyusun Rencana Kerja Penyuluhan Perikanan (RKPP) Kecamatan Junjuang Sirih Kabupaten Solok Provinsi Sumatera Barat.

\section{BAHAN DAN METODE}

\section{Waktu dan Tempat}

Kegiatan Penelitian dilaksanakan pada tanggal 1 Oktober sampai dengan 30 Oktober 2019 yang bertempat di Kecamatan Junjuang Sirih Kabupaten Solok Provinsi Sumatera Barat.

\section{Metode dan Alat Pengumpul Data}

Data sekunder yang akan diambil di Kecamatan Junjuang Sirih Kabupaten Solok akan diperoleh dengan menggunakan metode wawancara dan observasi dokumen dan laporan. Pengambilan data primer dilakukan dengan menggunakan metode Participatory Rural Appraisal (PRA) atau Pemahaman Partisipatif Kondisi Pedesaan (PRA) yaitu pendekatan dengan metode yang memungkinkan masyarakat secara bersama-sama menganalisis masalah kehidupan dalam rangka merumuskan perencanaan dan kebijakan secara nyata.

\section{Populasi}

Populasi dari kegiatan Penelitian adalah seluruh pelaku usaha meliputi: pembudidaya, pengolah, nelayan serta pemasar yang ada di Kecamatan Junjuang Sirih Kabupaten Solok Provinsi Sumatera Barat.

\section{Penentuan Desa Sampel}

Kecamatan Junjung Sirih memiliki dua desa, kedua desa tersebut berpotensi perikanan. Penulis mengambil keduanya, desa tersebut antara lain adalah: 1) Desa Muaro Pingai 2) Desa Paninggahan, penulis sebelumnya juga berkonsultasi dengan penyuluh dan Camat Kecamatan Junjung Sirih. Kedua desa tersebut diambil, kedua desa tersebut berpotensi dan juga terdapat beberapa kelompok perikanan yang dibina oleh penyuluh Kecamatan Junjuang Sirih yang sekaligus menjadi pembimbing eksternal penulis nanti saat di lapangan. Pengambilan desa di Kecamatan Junjuang Siriah dengan metode Sensus.

\section{Penentuan Responden}

Populasi dalam penelitian ini adalah masyarakat pelaku utama dan pelaku usaha perikanan di Kecamatan Junjuang Sirih Kabupaten Solok. Jumlah pelaku utama perikanan yang ada dalam seluruh desa sampel berjumlah 194 pelaku usaha perikanan dimana 51 orang merupakan pengolah, 63 orang merupakan pembudidaya dan 80 sebagai nelayan danau. Penentuan responden dengan metode Snowball dengan menemui tokoh masyarakat/ pamong desa untuk diarahkan menemui pelaku utama dan anggota kelompok perikanan yang ada di desa sampel yang aktif sebagai responden, dan didapatkan 15 responden

\section{Analisis Data}

Dalam melakukan pengolahan data akan digunakan metode analisis deskriptif dan analisis statistik. Dalam identifikasi potensi perikanan di Kecamatan Junjuang Sirih ada beberapa variabel yang akan dilihat yaitu mengenai karakteristik sumber daya alam, sumber daya manusia, sistem produksi perikanan, sistem usaha perikanan serta sistem penyuluhan perikanan. Dari beberapa 
Available online di: http://ejournal-balitbang.kkp.go.id/index.php/JSJ/index

variabel inilah akan dilihat bagaimana pengaruh variabel-variabel tersebut terhadap kegiatan perikanan yang ada di Kecamatan Junjuang Sirih yang kemudian data-data tersebut akan dijabarkan secara kualitatif dan kuantitatif dengan menghubungkan pengaruh antara variabel yang dititik beratkan pada potensi wilayah yang ada di lokasi praktik, kemudian perumusan:
a. Perumusan Keadaan
b. Perumusan Masalah
c. Perumusan Tujuan
d. Pembuatan, Konsultasi dan Pembahasan RKPP

\section{HASIL DAN PEMBAHASAN}

\section{Kondisi Potensi dan Permasalahan Sumber Daya Alam \\ Kondisi Umum Kecamatan Junjuang Sirih}

Secara geografis menurut Badan Pusat Statistik Kecamatan Junjuang Sirih, Wilayah Kecamatan Junjuang Sirih merupakan salah satu Kecamatan di Kabupaten Solok yang secara astronomis, Kecamatan Junjuang Sirih terletak antara 00 39' 23" dan 00 44' 55" Lintang Selatan $100^{\circ} 25^{\prime} 00^{\prime \prime}$ dan $100^{\circ} 33^{\prime} 4^{\prime \prime}$ Bujur Timur, dengan hamparan wilayah yang landai. Berdasarkan posisi geografisnya, Kecamatan Junjuang Sirih memiliki batas-batas: Utara - Kabupaten Tanah Datar, Selatan - Kecamatan X Koto Singkarak, Barat - Padang Pariaman dan Timur - Kecamatan $X$ Koto Singkarak.

Luas Wilayah Kecamatan Junjuang Sirih terdiri dari 2 desa dengan luas lahan $102,50 \mathrm{Km}^{2}$, yang berarti Kecamatan Junjuang Sirih hanya sekitar 3,93\% dari luas Wilayah Kabupaten Solok (yaitu kurang lebih $3.738 \mathrm{Km}^{2}$ ) dengan ketinggian tempat antara 400-800 m diatas permukaan laut yang terdiri dari lahan sawah $661 \mathrm{Ha}$, lahan darat $7.718 \mathrm{Ha}$ dan lainnya $18.71 \mathrm{Ha}$ luas lainnya. (https:JujuangSirih.bps.go.id). Peta wilayah Kecamatan Junjuang Sirih dapat dilihat pada Gambar 1.

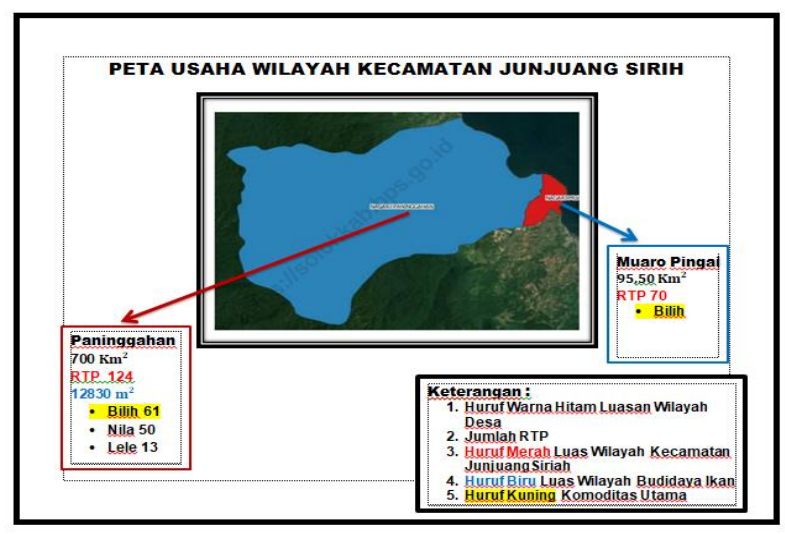

Gambar 1. Peta Kecamatan Junjuang Sirih.

Air sebagai salah satu kebutuhan pokok dalam kebutuhan pelaksanaan kegiatan budidaya ikan cukup tersedia dalam sepanjang tahun.air sangat diperlukan baik untuk kebutuhan kehidupan manusia, sumber pengairan budidaya perikanan maupun pertanian. Hampir keseluruhan pembudidaya menggunakan sumber air yang berasal dari sungai dikarenakan sungai mengalir sepanjang tahun bahkan di saat kemarau. Sumber mata air di kecamatan berasal dari beberapa sungai, dapat dilihat pada Tabel 1. 
Buletin JSJ, 3 (1), 2021, 29-42

Available online di: http://ejournal-balitbang.kkp.go.id/index.php/JSJ/index

Tabel 1. Sumber Mata Air Kecamatan Junjuang Sirih

\begin{tabular}{lcc}
\hline \multicolumn{1}{c}{ Nama Sungai } & Kecamatan & Lokasi \\
\multicolumn{1}{c}{$(\mathbf{2})$} & $\mathbf{( 3 )}$ & $\mathbf{( 4 )}$ \\
\hline Batang Paninggahan & Junjuang Sirih & Paninggahan \\
Batang Ulu Air & Junjuang Sirih & Paninggahan \\
Batang Ondoh & Junjuang Sirih & Paninggahan \\
Batang Rimbo Panjang & Junjuang Sirih & Muaro Pingai \\
Batang Taraso & Junjuang Sirih & Muaro Pingai \\
\hline Sumber: Data Dinas Perikanan dan Pangan Kab Solok 2019
\end{tabular}

Tabel 1. menunjukkan air yang digunakan pembudidaya untuk kegiatan budidaya ikan nila dan lele, Desa Paninggahan memanfaatkan sumber air yang ada di desanya, sedangkan Desa Muaro Pingai belum memanfaatkan sumber air dengan baik. Curah hujan rata-rata dalam kurun waktu sepuluh tahun di Kecamatan Junjuang Sirih Kabupaten Solok menurut data Pengelola Sumber Daya Air Kabupaten Solok dapat dilihat pada Tabel 2.

Tabel 2. Rata-rata curah hujan 10 tahun terakhir

\begin{tabular}{lcc}
\hline Bulan & $\begin{array}{c}\text { Curah Hujan } \\
(\mathbf{m m})\end{array}$ & $\begin{array}{c}\text { Hari Hujan } \\
(\mathbf{H H})\end{array}$ \\
\hline \multicolumn{1}{c}{$(\mathbf{1})$} & $\mathbf{( 2 )}$ & $\mathbf{( 3 )}$ \\
\hline Januari & 12,0 & 7 \\
Februari & 113,0 & 17 \\
Maret & 360,0 & 21 \\
April & 104,6 & 14 \\
Mei & 214,5 & 20 \\
Juni & 116,0 & 11 \\
Juli & 39,0 & 11 \\
Agustus & 26,5 & 8 \\
September & 145,5 & 9 \\
Oktober & 151,8 & 18 \\
November & 53,0 & 16 \\
Desember & 99,0 & 10 \\
\hline Jumlah & $\mathbf{1 4 3 4 , 1}$ & $\mathbf{1 6 2}$ \\
Rata-rata & $\mathbf{1 1 9 , 5}$ & $\mathbf{1 4}$ \\
\hline Sumber: Dinas Pertanian Kabupaten Solok 2019
\end{tabular}

Rata-rata curah hujan di Kecamatan Junjuang Sirih adalah $119,5 \mathrm{~mm}$ per tahun dengan rata-rata hari hujan sebanyak 14 hari dengan curah hujan tertinggi terjadi pada bulan Maret dan curah hujan terendah terjadi di bulan Januari. Walaupun saat musim kemarau, kebutuhan air tetap tercukupi, dan ketika hujan secara langsung menambah volume sungai yang ada di Kecamatan Junjuang Sirih. Hal ini menunjukan bahwa budidaya ikan dapat dilakukan sepanjang tahun karena ketersediaan air yang mencukupi kebutuhan rumah tangga maupun untuk budidaya dan pertanian. Ketersediaan air juga menentukan keberhasilan dari dari budidaya, tetapi factor kualitas air sangat menentukan juga dalam aspek budidaya perikanan. Pengelolaan kualitas air untuk keperluan budidaya sangat penting karena mwdia hidup bagi organisme akuakultur. (Panggabean, Sasanti, \& Yulisman, 2016). Berikut potensi pemanfaatan lahan selain untuk pemukiman di Kecamatan Junjuang Sirih. Lahan yang yang digunakan untuk budidaya ikan nila terdapat pada jenis penggunaan lainnya dan lahan sawah, karena ada pembudidaya yang menggunakan sawah untuk pembesaran ikan nila. Persentase penggunaan lahan dapat dilihat pada Gambar 2. 
Buletin JSJ, 3 (1), 2021, 29-42

Available online di: http://ejournal-balitbang.kkp.go.id/index.php/JSJ/index

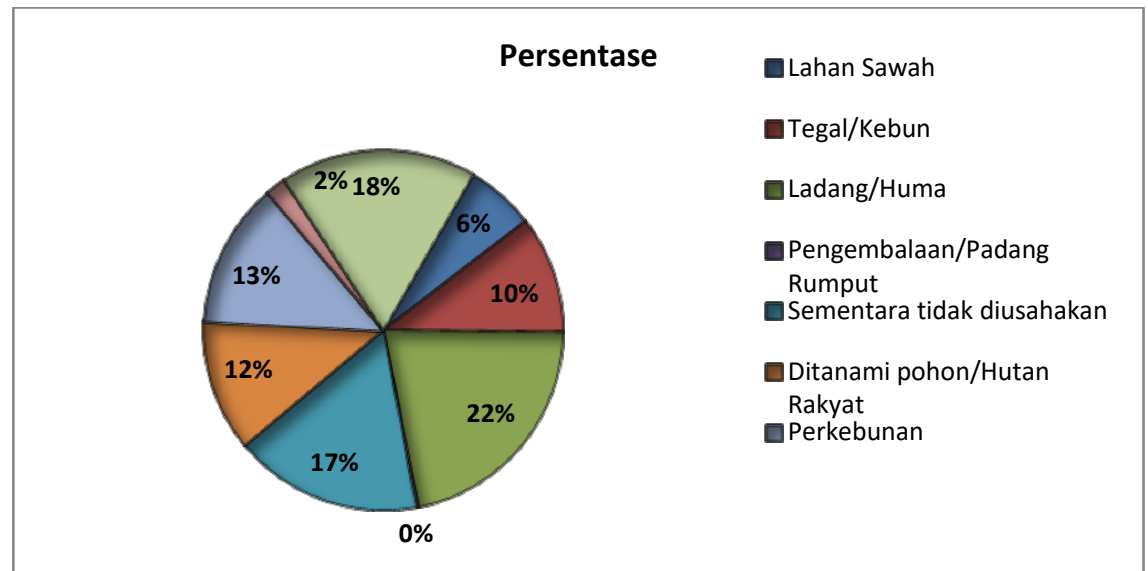

Gambar 2. Diagram Potensi Lahan.

Sumber: Dinas Pertanian, Peternakan dan Perikanan Kabupaten Solok 2019

Diagram diatas menunjukkan pemanfaatan paling banyak adalah kebun, dimana sawah juga memiliki potensi sebagai wadah pemeliharaan ikan dengan sistem mina padi dan lahan lainnya yang bisa digunakan untuk lahan budidaya perikanan. Lahan yang memiliki potensi juga untuk pemeliharaan ikan.

\section{Topografi}

Melihat dari keadaan topografi Kecamatan Junjuang Sirih yang sebagian besar wilayahnya adalah dataran tinggi dan pegunugan tipe iklim di Kecamatan Junjuang Sirih termasuk bervariasi, suhu berkisar antara $24-28^{\circ} \mathrm{C}$, jenis ikan yang cocok untuk dipelihara menurut(Saparinto \& Susiana, 2013), adalah, ikan mas yaitu hidup pada kebutuhan suhu rata-rata $20^{\circ}-30^{\circ} \mathrm{C}$, ikan lele yaitu hidup pada suhu $20^{\circ}-32^{\circ} \mathrm{C}$, ikan gurami hidup pada suhu $24^{\circ}-28^{\circ} \mathrm{C}$, dan ikan nila yaitu hidup pada suhu $25^{\circ} 30^{\circ} \mathrm{C}$ sedangkan menurut pendapat dengan Khairuman dam Amri (2014) bahwa ikan nila dapat tumbuh normal pada suhu $14^{\circ} \mathrm{C}$ hingga $38^{\circ} \mathrm{C}$.

\section{Keadaan Sumber Daya Manusia}

Menurut Badan Pusat Statistik Kecamatan Junjuang Sirih tahun 2019, jumlah penduduk. Kecamatan Junjuang Sirih pada tahun 2019 berdasarkan hasil registrasi penduduk adalah 12.197 jiwa. Kepadatan penduduk Kecamatan Junjuang Sirih pada Tahun 2019 adalah rata-rata 119 jiwa $/ \mathrm{Km}^{2}$, kepadatan penduduk tertinggi berada di Muara Pingai dengan kepadatan $251 \mathrm{jiwa} / \mathrm{Km}^{2}$ dan kepadatan terendah berada di Desa Paninggahan dengan kepadatan $109 \mathrm{jiwa} / \mathrm{Km}^{2}$.Berikut data kependudukan berdasarkan Data Badan Pusat Statistik Kecamatan Junjuang Sirih tahun 2019.

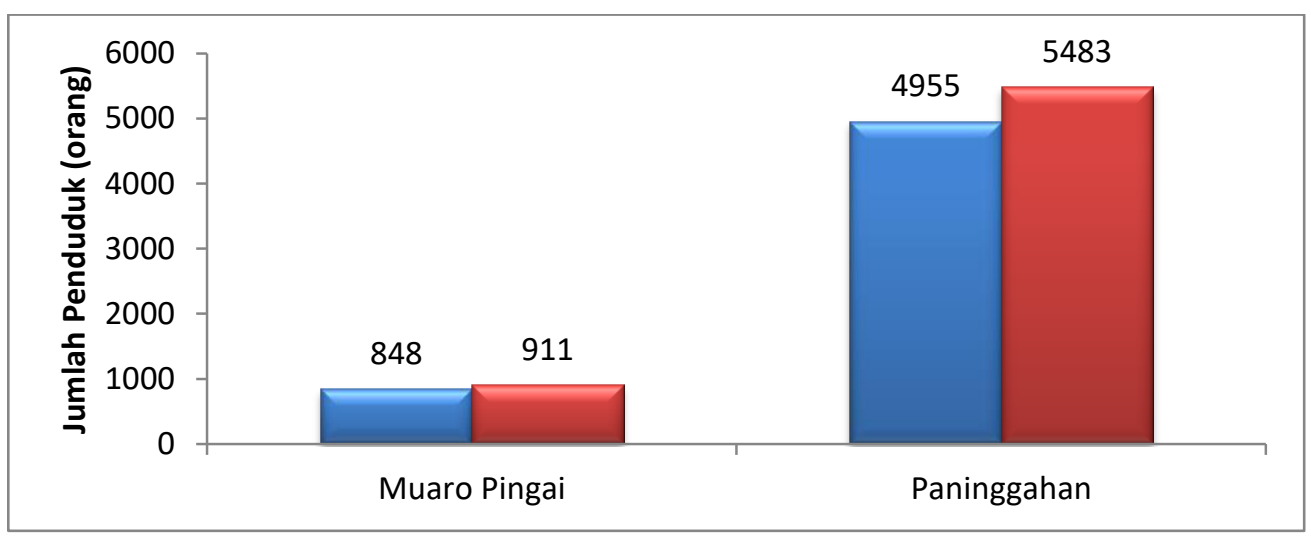

Gambar 3. Grafik Jumlah Penduduk Berdasarkan Jenis Kelamin. Sumber: BPS Kecamatan Junjuang Sirih 2019 
Dari data tersebut terlihat bahwa jumlah penduduk laki-laki dan perempuan ini menandakan berpotensi untuk menjadi pelaku utama perikanan dalam bidang budidaya, dan penangkapan dan penduduk perempuan untuk menjadi pelaku dibidang pengoalahan perikanan. Untuk lebih spesifik dalam jumlah penduduk yang dalam usia produktif, dapat dilihat pada grafik keadaan penduduk berdasarkan umur dibawah berikut.

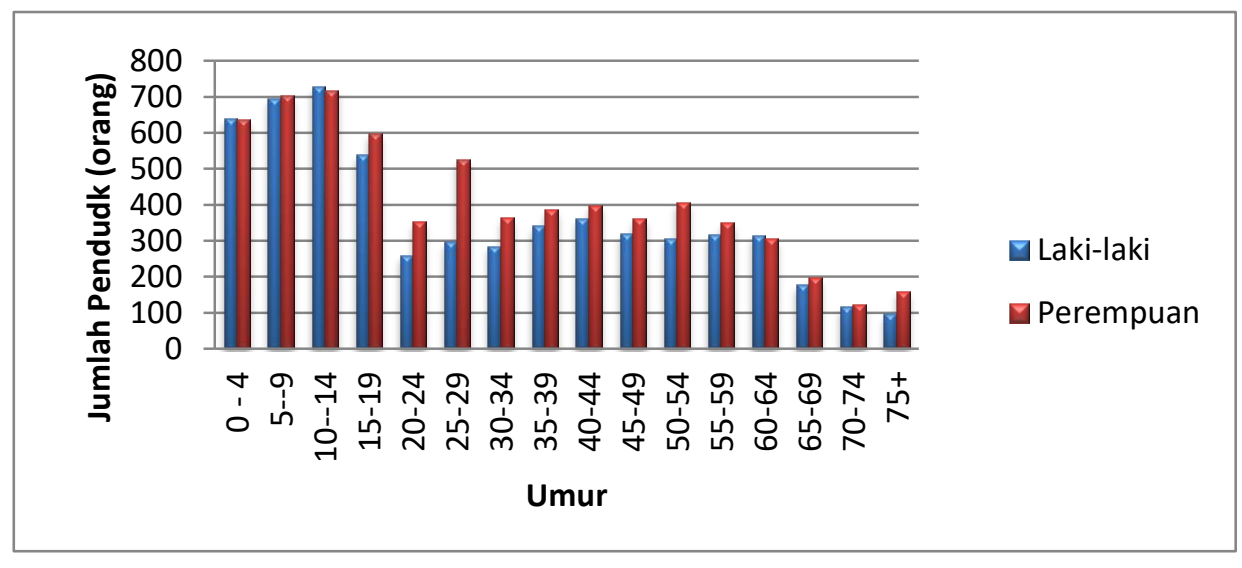

Gambar 4. Keadaan Penduduk Berdasarkan Kelompok Umur. Sumber: BPS Kabupaten Solok 2019

Gambar 4. menunjukkan umur produktif yang terdapat di Kecamatan Junjung Sirih. Berdasarkan kutipan dari situs resmi Badan Pusat Statistik ${ }^{1}$ bahwa angka beban tanggungan adalah angka yang menyatakan perbandingan antara penduduk dibawah usia produktif (dibawah 15 tahun dan 65 tahun keatas. Ini artinya bahwa usia produktif antara umur 15 hingga umur 64 tahun. Untuk usia produktif laki-laki sebanyak 3.348 dan perempuan sebanyak 4.050, yang artinya bahwa jumlah usia produktif lebih banyak perempuan dibanding usia produktif laki-laki. Laki-laki sebagai kepala keluarga di Kecamatan Junjuang Sirih rata-rata memiliki lebih dari satu pekerjaan.

\section{Kondisi Umum Usaha Perikanan}

Dari total penduduk di Kecamatan Junjuang Sirih terdapat \pm 194 Orang pelaku usaha perikanan yang tercatat berdasarkan data sekunder di Badan Penyuluh Perikanan, Pertanian dan Kehutanan (BP3K) dengan wilayah kerja yaitu Kecamatan Junjuang Sirih serta data yang diperoleh dari divisi statistik Dinas Pertanian, Perikanan Kabupaten Solok.

Dari total penduduk di Kecamatan Junjuang Sirih terdapat \pm 194 Orang pelaku usaha perikanan yang tercatat berdasarkan data sekunder di Badan Penyuluh Perikanan, Pertanian dan Kehutanann (BP3K) dengan wilayah kerja yaitu Kecamatan Junjuang Sirih serta data yang diperoleh dari divisi statistik Dinas Pertanian, Perikanan Kabupaten Solok. Berikut merupakan kondisi umum sumber daya manusia yang melakukan Usaha Perikanan Desa yang meliputi dua desa potensial perikanan di Kecamatan Junjuang Sirih dapat dilhat berdasarkan segmen usaha perikanannya secara rinci pada Gambar 5.

\footnotetext{
${ }^{1}$ httpsL//www.bps.go.id
} 
Buletin JSJ, 3 (1), 2021, 29-42

Available online di: http://ejournal-balitbang.kkp.go.id/index.php/JSJ/index

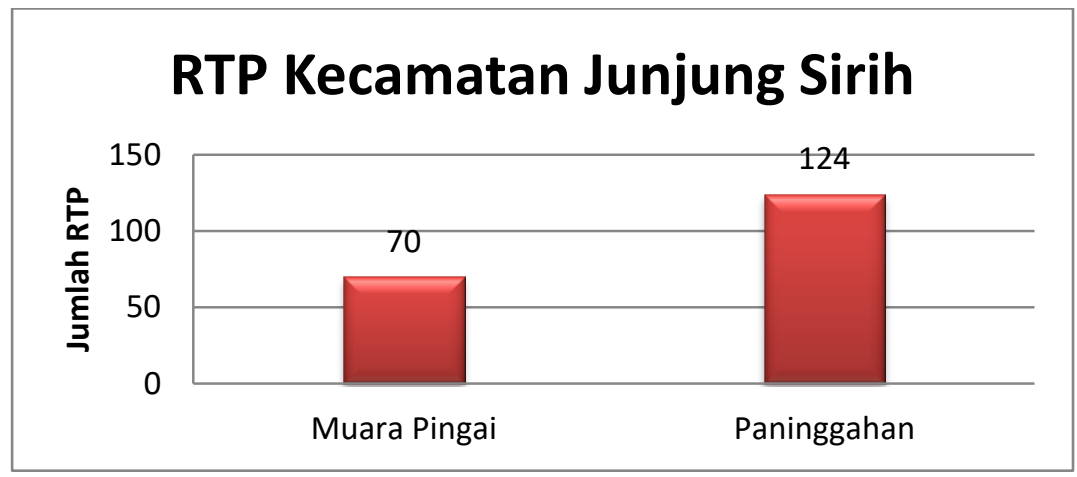

Gambar 5. Jumlah RTP di Kecamatan Junjung Sirih.

Sumber: Data Survey Penyuluh Kecamatan Junjung Sirih 2019

Tabel diatas hanya menggambarkan banyaknya pelaku utama maka yang ada di Kecamatan Junjuang Sirih, dari data diatas dapat dilihat pelaku utama terbanyak berada di Desa Paninggahan sebanyak 124 RTP, dan jumlah pelaku utama paling sedikit berada di Desa Muara Pingai yaitu sebanyak 70 RTP. Pendataan RTP dapat membantu dalam mendata jumlah kelompok perikanan, dan mempermudah dalam kelompok. Strategi dan mekanisme yang efektif membantu pembudidaya ikan skala kecil dalam mengatasi keterbatasan dan tetap kompetitif pada perubahan lingkungan usaha adalah dengan aksi bersama melalui partisipasi dalam kelompok (Hermawan, dkk 2017).

Komoditas pengolahan perikanan yang menjadi ciri khas daerah Kecamatan Junjung Sirih yaitu Ikan Bilih, karena di kecamatan tersebut memiliki Danau Singkarak yang memilik Sumber Daya Alam yang dapat dikembangkan dan digali potensinya, dari segi peluang dalam pengelolaan ikan bilih didukung oleh adanya potensi ikan bilih di Danau Singkarak, terbukanya bangsa pasar untuk ikan bilih segar maupun ikan olahan baik lokal maupun untuk ekspor dan komoditi ikan bilih merupakan penghasilan utama bagi nelayan serta dapat menyerap tenaga kerja. Dari sisi ancaman pengelolaan dan pelestarian ikan bilih, faktor terpenting yang harus diperhatikan adalah penangkapan ikan bilih saat sekarang masih ada yang dilakukan dengan menggunakan alat tangkap yang tidak ramah lingkungan yaitu bahan peledak, strom, adanya kecenderungan bertambahnya alat tangkap jaring insang (panjang 100 meter dan tinggi 2,5 meter) dengan mata jaring kecil (3/4 inci) dan berkurangnya jumlah jaring insang dengan luas mata jaring 1,0 inci sehingga ikan yang tertangkap lebih dominan sedang bertelur serta bertambahnya jumlah nelayan. Di Danau Toba ikan bilih hanya boleh ditangkap dengan jaring insang dengan ukuran mata jaring 1,25 inci dan 1,50 inci sehingga ukuran ikan yang tertangkap berkisar antara 15,0 - 18,5 cm (Kartamihardja, 2017)

\section{Kondisi Potensi dan Karakteristik Responden}

Responden yang didata saat Penelitian adalah pelaku utama perikanan, baik dari segmentasi pembesaran, pengolah maupun penangkapan. usia antara 36 hingga 61 atau usia produktif yang mendominasi dari keseluruhan responden yang diambil. Saat usia produktif adalah masa dimana para responden atau pelaku utama yang sedang giat-giatnya bekerja, dan semuanya memiliki pekerjaan lain untuk mencukupi kebutuhan keluarga. Umur, tingkat pendidikan dan lama usia mempengaruhi dari penghasilan responden, karakteristik responden di Kecamatan Junjuang Sirih dapat dilihat pada Tabel 3.

Tabel 3. Karakteristik Responden

\begin{tabular}{llcc}
\hline Kriteria & \multicolumn{1}{c}{ Kategori } & $\begin{array}{c}\text { Jumlah } \\
\text { responden } \\
\text { (orang) }\end{array}$ & $\begin{array}{c}\text { Presentase } \\
(\%)\end{array}$ \\
\hline Umur & Muda ( $\leq 35$ tahun) & 1 & 6,66 \\
& Sedang (36-61 tahun) & 14 & 93,33 \\
& Tua ( $\geq 62$ tahun) & 0 & 0 \\
\hline
\end{tabular}


Buletin JSJ, 3 (1), 2021, 29-42

Available online di: http://ejournal-balitbang.kkp.go.id/index.php/JSJ/index

\begin{tabular}{llcc}
\hline Tingkat pendidikan & Tinggi (D3-S3) & 1 & 6,66 \\
& Sedang (SLTP-SLTA) & 11 & 73,33 \\
& Rendah (Tidak sekolah-SD) & 3 & 20 \\
\hline Tahun mulai usaha & Lama ( tahun 2003) & 0 & 0 \\
& Cukup Lama ( tahun 2004-2015) & 3 & 20 \\
& Baru ( $\geq 2016)$ & 12 & 80 \\
\hline
\end{tabular}

Persentase usia dan tingkat pendidikan yang dominan pada responden yaitu kategori sedang, sedangkan jangka waktu usaha paling lama yaitu kategori baru ( $\geq 2016)$. Semakin lama menekuni bidang usaha perdagangan akan semakin meningkatkan pengetahuan selera ataupun perilaku konsumen (Nainggolan, 2016). Kecamatan junjuang Sirih memiliki potensi perikanan yang dominan dibandingkan daerah kecamatan yang lain yang berada di Kabupaten Solok, namun Kecamatan Junjuang Sirih termasuk daerah yang angka kecukupan gizi yang kurang, sehingga banyak anak-anak yang stunting. Pengkuran status gizi anak-anak bisa dilihat pada Tabel 4.

Tabel 4. Sampel Pengukuran Status Gizi Anak Sekolah Dasar

\begin{tabular}{lcccccccc}
\hline \multirow{2}{*}{ Nama } & \multirow{2}{*}{$\begin{array}{c}\text { Tanggal } \\
\text { Lahir }\end{array}$} & \multicolumn{4}{c}{$\begin{array}{c}\text { Jenis } \\
\text { Kelamin }\end{array}$} & \multicolumn{7}{c}{ STATUS GIZI } & \\
\cline { 5 - 8 } & & L & P & BB & TB & IMT & TB/U & Dirujuk \\
\hline Rahmatul Jannah H & $22 / 10 / 2010$ & & $\sqrt{ }$ & 21.1 & 113 & $\mathrm{~N}$ & $\mathrm{P}$ & $\sqrt{ }$ \\
Syamfatur Yahya & $14 / 6 / 2010$ & $\sqrt{ }$ & & 27 & 121 & $\mathrm{~N}$ & $\mathrm{~N}$ & \\
Decinta Bakhri & $12 / 2 / 2011$ & & $\sqrt{ }$ & 15.5 & 108 & $\mathrm{~N}$ & $\mathrm{SP}$ & $\sqrt{ }$ \\
Rasyidul Hadi Aspa & $10 / 7 / 2010$ & & $\sqrt{ }$ & 23.4 & 117 & $\mathrm{~N}$ & $\mathrm{P}$ & $\sqrt{ }$ \\
Naila Mutia & $27 / 2 / 2010$ & & $\sqrt{ }$ & 21 & 123 & $\mathrm{~N}$ & $\mathrm{~N}$ & \\
\hline
\end{tabular}

Ket :

$\mathrm{N}$ : Normal

$\mathrm{K}:$ Kurus

G : Gemuk

$P$ : Pendek

SP : Sangat

Pendek

Hasil data sampel siswa SDN 01 Muaro Pingai menunjukkan bahwa terdapat anak-anak yang memiliki TB/U yang pendek 2 Orang dan sangat pendek 1 orang, oleh karena itu 3 orang tersebut perlu di rujuk kembali untuk status gizinya.

\section{Budidaya}

Kegiatan budidaya ikan nila dan lele di Kecamatan Junjuang Sirih terdiri dari satu segmen usaha yaitu pembesaran yang terdapat Desa Paninggahan. Sebelum melakukan kegiatan produksi segmen usaha tersebut perlu dipersiapkan pasokan input berupa sarana produksi perikanan, tenaga kerja, serta modal. Pembesaran ikan yang di jalankan belum mengikuti CBIB yang sesuai. Kendala yang utama yang dirasakan kelompok pembudidaya adalah belum adanya pakan peganti pakan komersil. Keuntungan rat-rata yang di peroleh yaitu Rp. 6.916.542.

\section{Pengolahan}

Pengolahan Ikan Bilih Goreng di Desa Paninggahan dan Muaro Pingai menggunakan pengolahan dengan sistem tradisional Pengolahan ikan bilih goreng belum menerpakan sanitasi dan higenitasi produk. Peralatan yang digunakan masih sangat sederhana. Komoditas ikan bilih memiliki kandungan gizi yang tinggi, dan sangat bagus dikonsumsi oleh anak-anak untuk tumbuh, berkembang dan kecerdasan otak. Ikan bilih merupakan sumber protein hewani yang yang 
Available online di: http://ejournal-balitbang.kkp.go.id/index.php/JSJ/index

potensial untuk dikembangkan dengan kandungan protein sebesar 13,02\%. Disamping itu ikan bilih juga memilki kandungan mineral seperti kalsium 2,2 \%, magnesium 0,18 \%, phosphor 1,2\% (Permata dan Murtius, 2015)

\section{Penangkapan}

Penangkapan ikan yang dilakukan oleh nelayan di Kecamatan Junjuang Sirih yang bertempat di danau Singkarak. Peralatan yang digunakan belum ramah lingkungan. Danau Singkarak memiliki potensi perikanan yang baik terutama untuk komoditas endemik yaitu ikan bilih. Nelayan sangat menggantungkan hidupnya pada tangkapan danau. Keuntungan rata-rata yang diperoleh dari nelayan setiap bulan yaitu Rp. 3.654.1666/bulan.

\section{Pemasaran}

Kegiatan pemasaran biasanya dilakukan secara langsung maupun semi langsung sesuai dengan yang terdapat dalam pustaka, Dimana konsumen bahkan tengkulak pun datang sendiri ke lokasi usaha. Berikut merupakan alur pemasaran yang biasa dilakukan di Kecamatan Junjuang Sirih dapat dilihat pada Gambar 6.

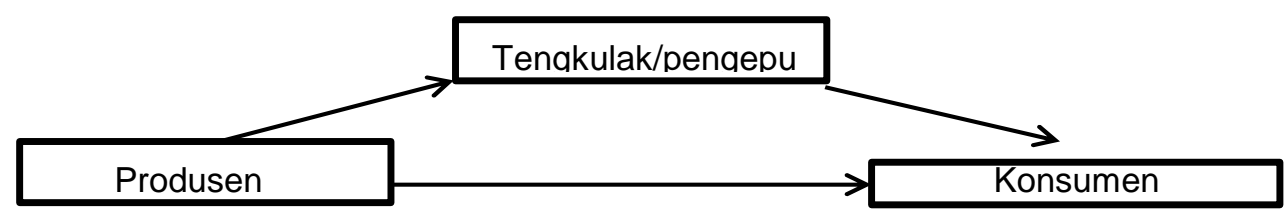

Gambar 6. Saluran Pemasaran di Kecamatan Junjuang Sirih.

\section{Analisis Usaha}

Analisa usaha yang dihitung dari 3 segmen baik pembesaran, penangkapan dan pengolahan adalah hitungan dalam jangka waktu setahun. Untuk analisis rataan data dapat dilihat pada Tabel 5.

Tabel 5. Hasil Rata-rata Analisis Usaha

\begin{tabular}{llll}
\hline Substansi & Budidaya/Siklus & $\begin{array}{l}\text { Penangkapan (One } \\
\text { Day Fishing) / thn }\end{array}$ & Pengolahan / bln \\
\hline Biaya Investasi & Rp. 404.591.333 & Rp. 49.166.667 & Rp. 5.563.333 \\
$\begin{array}{l}\text { Total biaya } \\
\text { Produksi }\end{array}$ & Rp. 8.096.791 & Rp. 61.150 .000 & Rp. 21.079.718 \\
Biaya tetap & Rp. 329.124 & Rp. 9.350 .000 & Rp. 498.052 \\
Biaya variable & Rp. 23.330.000 & Rp. 51.800.000 & Rp. 20.581.667 \\
Pendapatan & Rp. 15.013 .333 & Rp. 105.000 .000 & Rp. 28.160.000 \\
Keuntungan & Rp. 6.916.542 & Rp. 43.850 .000 & Rp. 7.080.282 \\
BEP (rupiah) & Rp. 538.806 & Rp. 17.567 .707 & Rp. $7,725(\mathrm{Kg})$ \\
BEP (unit) & 26,3 kg & 338.470 ekor & Rp. 1.844 .635 \\
R/C & 1,64 & 1.69 & 1,32 \\
ROI & $54,9 \%$ & $85 \%$ & $32,5 \%$ \\
PP & 19,1 tahun & 1,16 tahun & 0,07 tahun \\
\hline
\end{tabular}

Berdasarkan Tabel 6. rata-rata analisis usaha yang diddapatkan dengan R/C diatas 1 . Usaha yang dilakukan sudah layak dari segi ekonomois. Potensi perikanan yang ada di Kecamatan Junjuang Sirih sangat mendukung dan sangat baik untuk dikembangkan.

\section{Kelembagaan Penyuluhan}

Kelembagaan Penyuluh Perikanan yang ada di Kabupaten Solok adalah Dinas Perikanan dan Pangan (DPP) Kabupaten Solok. Selama melaksanakan Penelitian selalu berkoordinasi dengan dinas tersebut. Kecamatan Junjung Sirih juga memiliki fasilitas Pos Penyuluh Perikanan 
Buletin JSJ, 3 (1), 2021, 29-42

Available online di: http://ejournal-balitbang.kkp.go.id/index.php/JSJ/index

(POSLUHKAN). Untuk lebih jelasnya dapat dilihat pada tabel berikut. Berikut Lembaga penyuluhan perikanan Kabupaten Solok Provinsi Sumatera Barat.

Tabel 6. Lembaga Peyuluhan Perikanan

\begin{tabular}{lll}
\hline \multicolumn{1}{c}{ Kelembagaan } & \multicolumn{1}{c}{ Tingkat } & \multicolumn{1}{c}{ Alamat } \\
\hline Dinas Perikanan dan Pangan Kab. Kabupaten & JL. Raya Koto Baru, Koto Baru, Kec. \\
Solok & Kubung, Solok, Sumatera Barat. \\
Koordinator Instansi Perairan Umum Kabupaten & JL. Lintas Sumatera Km. 14, Singkarak \\
$\begin{array}{l}\text { Danau Singkarak } \\
\text { Pos Penyulluh Perikanan }\end{array}$ & $\begin{array}{l}\text { Kabupaten Solok Sumatera Barat } \\
\text { Kecamatan }\end{array}$ & $\begin{array}{l}\text { JL. Raya Koto Baru, Koto Baru, Kec. } \\
\text { Kubung, Solok, Sumatera Barat. }\end{array}$ \\
\hline
\end{tabular}

Lembaga penyuluhan perikanan diatas sekaligus sebagai layanan pendukung usaha perikanan Kecamatan Junjung Sirih, dimana Dinas Perikanan dan Pangan Kabupaten Solok dengan memberikan bentuk dukungan pada kegiatan usaha polikultur dengan menjalankan program kebijakan yaitu pemberian bantuan berupa benih dan pupuk serta program pengembagan komoditas unggulan berorientasi bisnis perikanan. Kantor Koordinantor Instansi Perairan umum Danau Singkarak Kabupaten Solok berperan untuk mengawasi perairan umum danau singkarak, yang mewakili perairan umum Provinsi. Pos Penyuluhan Perikanan (POSLUHKAN) berada dalam wilayah Kabupaten Solok, adalah tempat pertemuan para penyuluh, pelaku utama, pelaku usaha untuk melaksanakan penyuluhan di Kecamatan dan Desa untuk menjembatani pembudidaya dalam menangani suatu masalah melalui kegiatan rembug, temu teknis.

\section{Keragaan Kelompok dan penyuluhan}

Gambaran kinerja penyuluh di Kabupaten Solok masih belum teralalu optimal dikarenakan jumlah peyuluh perikanan yang ada di Kabupaten Solok masih kurang, sehingga hamplr semua penyuluh yang memegang dua kecamatan yang jadi daerah bianaannya. Penyuluh Perikanan di Kecamatan Junjuang Sirih adalah penyuluh PNS yaitu Ulfauza, S. Pi. Sasaran penyuluhan perikanan di Kecamatan Junjung Sirih adalah kelompok pembudidaya ikan, penangkapan dan pengolah yang tersebar di dua desa tersebut. Kelompok di Kecamatan Junjung Sirih saat ini ada 14 kelompok. Daftar nama kelompok perikanan yang ada di Kecamatan Junjung Sirih dapat dilihat pada Tabel 7.

Tabel 7. Keragaan Kelompok Perikanan di Kecamatan Junjuang Sirih

\begin{tabular}{|c|c|c|c|c|}
\hline Desa & Kelompok & $\begin{array}{c}\text { Jumlah Anggota } \\
\text { (Orang) }\end{array}$ & Ketua & $\begin{array}{c}\text { Bidang Usaha } \\
\text { Perikanan }\end{array}$ \\
\hline Muaro Pingai & Bilih 7 Muaro & 7 & Titi Relawati & $\begin{array}{l}\text { Pengolahan Ikan } \\
\text { Bilih }\end{array}$ \\
\hline Paninggahan & Tabing Biduk Lestari & 12 & Lastri & $\begin{array}{l}\text { Pengolahan Ikan } \\
\text { Bilih }\end{array}$ \\
\hline Paninggahan & Panca Riak & 10 & Nopel & $\begin{array}{l}\text { Pengolahan Ikan } \\
\text { Bilih }\end{array}$ \\
\hline Paninggahan & Ondoh Jaya Makmur & 10 & $\begin{array}{l}\text { Halim } \\
\text { Muarif }\end{array}$ & Nelayan \\
\hline Paninggahan & Anugerah & 10 & Kasnita & $\begin{array}{l}\text { Pengolahan Ikan } \\
\text { Bilih }\end{array}$ \\
\hline Paninggahan & Bawah Gaung & 12 & $\begin{array}{l}\text { Yanto Dt } \\
\text { Sinaro }\end{array}$ & Budidaya Nila \\
\hline Paninggahan & Grapu Mandiri & 16 & Mulyadi & Budidaya Nila \\
\hline Paninggahan & Taha Sepakat & 10 & Nurlis & Budidaya Nila \\
\hline Paninggahan & Harapan Jaya & 14 & Safrida & Budidaya Lele \\
\hline
\end{tabular}


Buletin JSJ, 3 (1), 2021, 29-42

Available online di: http://ejournal-balitbang.kkp.go.id/index.php/JSJ/index

\begin{tabular}{|c|c|c|c|c|}
\hline Paninggahan & Suka Maju Ribu-ribu & 13 & Suhartati & Budidaya Lele \\
\hline Paninggahan & Poklahsar Djamber & 12 & Ita & $\begin{array}{l}\text { Pengolahan Ikan } \\
\text { Bilih }\end{array}$ \\
\hline Paninggahan & Nelayan Perorangan & 50 & Nofrizal & Nelayan \\
\hline Paninggahan & Muaro Kacik & 10 & Supriadi & Nelayan \\
\hline Paninggahan & KUB Sisiak Bilih & 10 & Agusrizal & Nelayan \\
\hline
\end{tabular}

Sumber: Data Penyuluh Perikanan Kecamatan Junjuang Sirih 2019

Berdasarkan tabel keragaan kelompok perikanan, kelompok didominasi oleh kelompok penangkapan dan pengoalah dengan komoditas yang ditangkap dan diolah adalah ikan bilih sesuai dengan komoditas utama di Kecamatan Junjung Sirih yaitu Ikan Bilih. Dalam kelompok pengolahan, terdapat 5 kelompok pengolah, 4 Kelompok Nelayan dan 5 Kelompok Pembudidaya. Kelompok pengolahan termasuk usaha yang layak, namun belum adanya diversifikasi olahan ikan baru serta sanitasi dan higenitas produk yang belum diperhatikan, serta kurangnya relasi pemasaran dan minimnya jiwa enterpreneur atau jiwa berdagang karena malu untuk memasarkan produksinya kepada konsumen. Dari 14 kelompok perikanan yang ada di Kecamatan Junjung Sirih, diambil sampel penilaian fungsi kelompok sejumlah 5 kelompok. Adapun Rata-rata fungsi kelompok budidaya di Kecamatan Junjung Sirih antara lain.

Tabel 8. Penilaian Fungsi Kelompok

\begin{tabular}{|c|c|c|c|c|c|}
\hline FUNGSI & $\begin{array}{l}\text { Muaro } \\
\text { Kaciak }\end{array}$ & $\begin{array}{l}\text { KUB Sisiak } \\
\text { Bilih }\end{array}$ & $\begin{array}{l}\text { Bilih } 7 \\
\text { Muaro }\end{array}$ & $\begin{array}{l}\text { Poklahsar } \\
\text { Djamber }\end{array}$ & $\begin{array}{c}\text { Taha } \\
\text { Sepakat }\end{array}$ \\
\hline $\begin{array}{l}\text { Fungsi kelompok sebagai } \\
\text { wahana belajar }\end{array}$ & 2.7 & 3.3 & 4 & 4 & 3.3 \\
\hline $\begin{array}{l}\text { Fungsi kelompok sebagai } \\
\text { wahana kerjasama }\end{array}$ & 3.2 & 3.8 & 3.5 & 3.7 & 3.0 \\
\hline $\begin{array}{l}\text { Fungsi kelompok sebagai } \\
\text { unit produksi }\end{array}$ & 2.7 & 2.7 & 2.7 & 2.7 & 2.3 \\
\hline Unit usaha atau bisnis & 2 & 2.25 & 2.5 & 2.25 & 2.25 \\
\hline Kesatuan swadaya swadana & 1.8 & 2.6 & 2.4 & 2.6 & 2 \\
\hline $\begin{array}{l}\text { Unit penyediaan sarana dan } \\
\text { prasarana produksi }\end{array}$ & 2 & 3 & 2 & 2 & 2 \\
\hline $\begin{array}{l}\text { Unit pengolahan dan } \\
\text { pemasaran }\end{array}$ & 2.7 & 3.3 & 2.7 & 3.3 & 3.0 \\
\hline Unit jasa penunjang & 2.5 & 3.0 & 3.0 & 2.5 & 3.0 \\
\hline Jumlah & 19.6 & 23.9 & 22.8 & 23,05 & 20.85 \\
\hline Rata-rata & 2.45 & 2.9 & 2.85 & 2.8 & 2.6 \\
\hline
\end{tabular}

Keterangan:

$1-1,7=$ KURANG

$1,8-2,5=$ CUKUP

$2,6-3,3=$ BAIK

$3,4-4,0=$ SANGAT BAIK

Berdasarkan Tabel 8, fungsi kelompok yang memiliki nilai tertinggi adalah fungsi kelompok sebagai wahana belajar. Penyuluh perikanan Kecamatan Junjuang Sirih memiliki kontribusi yang cukup besar bagi para pembudidaya untuk kegiatan wahana belajar, dimana dalam pertemuan kelompok yang minimal dilakukan sebulan tiga kali untuk membahas kegiatan-kegiatan yang berkaitan dengan pengetahuan tentang teknologi perikanan maupun permasalahan dan kendala yang dihadapi oleh pembudidaya, pengolah dan nelayan. Nilai terendah adalah unit penyediaan sarana dan produksi dimana dalam kegiatan kelompok belum mampu menyediakan pakan, pupuk 
Available online di: http://ejournal-balitbang.kkp.go.id/index.php/JSJ/index

maupun benih secara mandiri. Fungsi kelompok sebagai kesatuan swadaya dan swadana juga belum terlaksana baik dikarenakan belum adanya iuran wajib kelompok untuk menunjang kegiatan usaha bersama dalam kelompok. Hubungan msyarakat kelompok perikanan dengan kelembagaan bisa dilihat pada diagram venn pada Gambar 7.

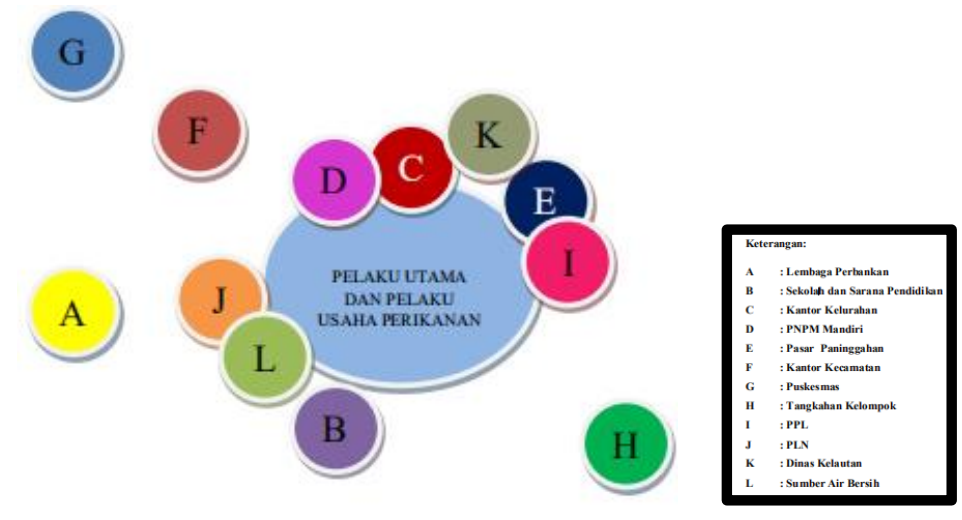

Gambar 7. Diagram Venn.

Berdasarkan diagram Venn tersebut diketahui bahwa hal yang berhubungan langsung dalam suatu kegiatan usaha pelaku utama dan pelaku usaha perikanan yaitu ketersediaan PNPM Mandiri, Kantor Kelurahan, Pasar Paninggahan, PPL dan Sumber Air Bersih. Penyuluh melakukan koordinasi dengan Dinas Perikanan dan Pangan Kabupaten Solok, adanya pasar sebagai sarana penyalur hasil panen ke konsumen dan peran serta kantor kecamatan dan kantor kelurahan di Desa Muaro Pingai dan Paninggahan. Evaluasi yang dilakukan sekali dalam setahun. Ada beberapa pihak yang terlibat dan memberikan penilain dalam evaluasi tahunan. Evaluasi oleh petugas Dinas Perikanan dan Pangan Kabupaten Solok, koordinator penyuluh perikanan, Kepala Desa di Kecamatan Junjung Sirih dan penyuluh itu sendiri. Salah satu hasil kegiatan evaluasi penyuluhan adalah penilaian kelas kelompok sebagaimana tersaji pada Tabel 9.

Tabel 9. Kelas Kelompok di Kecamatan Junjuang Sirih

\begin{tabular}{|c|c|c|c|c|c|}
\hline No & Kelompok & $\begin{array}{c}\text { Jumlah } \\
\text { Anggota }\end{array}$ & Tahun Berdiri & $\begin{array}{c}\text { Kelas } \\
\text { Kelompok }\end{array}$ & $\begin{array}{c}\text { Bidang Usaha } \\
\text { Perikanan }\end{array}$ \\
\hline 1. & Bilih 7 Muaro & 7 & 2004 & Pemula & Pengolahan \\
\hline 2. & $\begin{array}{l}\text { Tabing Biduk } \\
\text { Lestari }\end{array}$ & 12 & 2012 & Pemula & Pengolahan \\
\hline 3. & Panca Riak & 10 & 2014 & Pemula & Pengolahan \\
\hline 4. & $\begin{array}{l}\text { Ondoh Jaya } \\
\text { Makmur }\end{array}$ & 11 & 2017 & Pemula & Penangkapan \\
\hline 5. & Anugerah & 10 & 2015 & Pemula & Pengolahan \\
\hline 6. & Bawah Gaung & 10 & 2015 & Pemula & Pengolahan \\
\hline 7. & Grapu Mandiri & 16 & 2011 & Pemula & Budidaya \\
\hline 8. & Taha Sepakat & 10 & 2017 & Pemula & Budidaya \\
\hline 9. & Harapan Jaya & 12 & 2018 & Pemula & Budidaya \\
\hline 10 & $\begin{array}{l}\text { Suka Maju Ribu- } \\
\text { ribu }\end{array}$ & 13 & 2019 & Pemula & Budidaya \\
\hline 11. & $\begin{array}{l}\text { Poklahsar } \\
\text { Djamber }\end{array}$ & 12 & 2019 & Pemula & Pengolahan \\
\hline 12. & $\begin{array}{l}\text { Nelayan } \\
\text { Perorangan }\end{array}$ & 50 & 2017 & Pemula & Penangkapan \\
\hline 13. & Muaro Kaciek & 10 & 2018 & Pemula & Penangkapan \\
\hline
\end{tabular}


Buletin JSJ, 3 (1), 2021, 29-42

Available online di: http://ejournal-balitbang.kkp.go.id/index.php/JSJ/index

14. KUB Sisiak Bilih 10
Sumber: DPP Kab. Solok (2019)
Berdasarkan data di atas kelompok perikanan yang ada di Kecamatan Junjuang Sirih masih
termasuk kelas kelompok pemula, belum ada kelompok perikanan madya ataupun utama.
Peningkatan kelas kelompok sangat dipengaruhi oleh kinerja penyuluhan dan pemberdayaan
petani dalam kelompoknya (Margolang, 2018).

\section{Hasil Identifikasi Permasalahan}

Berdasarkan hasil dan pembahasan penelitian yang sudah dijalani selama kurang lebih 1 bulan, dengan pengambilan data melalui metode wawancara, observasi dan survey langsung, maka dapat ditarik permasalahan umum yang terdapat di Kecamatan Junjuang Sirih Kabupaten Solok adalah sebagai berikut:

a.Kurangnya pengetahuan pelaku utama mengenai relasi pemasaran, baik budidaya penangkapan dan pengolahan.

b. Nelayan belum menggunakan combine fishing yan ramah lingkungan

c. Belum mampu melakukan pencatatan administrasi kelompok secara tertib dan rutin pada buku administrasi kelompok dan bermanfaat berkelompok.

d. Kurangnya pengetahuan pelaku utama tentang diversifikasi olahan ikan bilih pada kelompok pengolah ikan bilih serta sanitasi dan higenis.

e. Gizi anak-anak yang masih rendah dan stunting yang terjadi pada anak usia dini di wilayah Kecamatan Junjuang Sirih.

\section{KESIMPULAN DAN SARAN}

Luas Wilayah Kecamatan Junjuang Sirih terdiri dari 2 desa dengan luas lahan 10,250 hektar yang terdiri dari lahan sawah $661 \mathrm{Ha}$, lahan darat 2.890,25 hektar (termasuk didalamnya terdapat luas kolam 9589 hektar dan dialiri oleh 4 sungai yang bersumber dari mata air Gunung Talang. Usia produktif di Kecamatan Junjung Sirih laki-laki sebanyak 5.803 dan perempuan sebanyak 6.394, yang artinya bahwa jumlah usia produktif lebih banyak perempuan dibanding usia produktif laki-laki, yang artinya selain usaha budidaya ikan, usaha pengolahan ikan juga memiliki peluang untuk dijalankan jika dikembangkan karena usia produktif wanita yang lebih tinggi selaras dengan usaha pengolahan yang biasanya dilakukan oleh wanita. Hasil analisis permasalah penangkapan yaitu belum menggunakan alat tangkap ramah lingkungan selama penangkapan ikan. Permasalahan budidaya yaitu belum melakukan budidaya CBIB dan harga pakan komersial yang mahal. Bidang pengolahan belum menerapkan sanitasi dan higenitas. Produk olahan juga belum banyak dikonsumsi oleh anak-anak. Rekomendasi praktek akhir adalah perlunya penggunaan alat tangkap ramah lingkungan, perlunya membuat pakan alternative pengganti pakan komersial dan peningkatan sanitasi higienis serta status gizi anakanak masih perlu untuk dirujuk kembali. Permasalahan pada kelompok perikanan yaitu masih rendahnya Peran dan fungsi kelompok pada aspek unit produksi dalam pengadaan SAPROKAN terutama penyediaan pakan buatan. Kegiatan pelaksaan kegiatan penyuluhan yang akan dilakukan telah dibahas dan dimasukka didalam RKPP.

\section{DAFTAR PUSTAKA}

Hermawan, A., Amanah, S., \& Fatchiya, A. (2017). Jurnal Penyuluhan, Maret 2017 Vol. 13 No. 1 Partisipasi Pembudidaya Ikan dalam Kelompok Usaha Akuakultur di Kabupaten Tasikmalaya, Jawa Barat. 13(1), 1-13.

Gunarto, A. 2009. Pelestarian Ikan Bilih (Mystacoleucus padangensis) Melalui Pengembangan Agrowisata Perikanan di Danau Singkarak Sumatera Barat. JRL. 5 (2): 145-156.

Kartamihardja, E. S. (2017). Pengelolaan Sumberdaya Ikan Bilih (Mystacoleucus padangensis) Introduksi di Danau Toba, Sumatera Utara. Jurnal Kebijakan Perikanan Indonesia, 1(2), 87. 
Buletin JSJ, 3 (1), 2021, 29-42

Available online di: http://ejournal-balitbang.kkp.go.id/index.php/JSJ/index

https://doi.org/10.15578/jkpi.1.2.2009.87-98

Khairuman., \& Amri, K. (2014). Bisnis Pembenihan Ikan Konsumsi. Jakarta: Gramedia Pustaka Utama.

Margolang, N. (2018). Strategi Peningkatan Kelas Kemampuan Kelompok Tani. Agro Riau, (2), 118.

Musyawir Amra. (2019). Rencana Kegiatan Penyuluhan Perikanan. Solok.

Nainggolan, R. (2016). Gender, Tingkat Pendidikan Dan Lama Usaha Sebagai Determinan Penghasilan Umkm Kota Surabaya. Kinerja, 20(1), 1. https://doi.org/10.24002/kinerja.v20i1.693

Panggabean, T. K., Sasanti, A. D., \& Yulisman. (2016). Kualitas Air, Kealngsungan Hidup, Pertumbuhan dan Efesiensi Pakan Ikan Nila yang diberi pupuuk Hayati Cair Pada Air Media Pemeliharaan. Jurnal Penyuluhan Perikanan Dan Kelautan, 4 (1) 67-.

Permata, D. A., \& Murtius, W. S. (2015). Kandungan zat gizi dan bakteri proteolitik pada produk olahan ikan bilih. Teknologi Pertanian, 19(1), 10-14.

Primyastanto, \& Pito. (2011). MINAPOLITAN: Suatu Pendekatan Ekonomi, Sosial, Lingkungan, dan Agama. Malang: Universitas Brawijaya Press.

Purnomo, K., Kartamihardja, E. S., Koeshendrajana, S. 2006. Upaya Pemacuan Stok Ikan Bilih (Mystacoleucus padangensis) di Danau Singkarak. Prosiding Seminar Nasional Ikan IV Jatiluhur. 11-18.

Saparinto, C., \& Susiana, R. (2013). Sukses Pembenihan 6 Jenis Ikan Air Tawar. Yogyakarta.

Suryono, T., S. Nomosatryo., E. Mulyana. 2006. Tingkat Kesuburan Danau Singkarak, Padang, Sumatera Barat. Pusat Penelitian Limnologi - LIPI. (Tidak diterbitkan).

Syandri. 2008. Ancaman terhadap Plasma Nutfah Ikan Bilih (Mystacoleucus padangensis) dan Upaya Pelestariannya di Danau Singkarak. Universitas Bung Hatta, Padang.

Wendri, Y., Nurdin, J., \& Zakaria, I.J. (2019). Komunitas dan Preferensi Habitat Gastropoda pada Kedalaman Berbeda di Zona Litoral Danau Singkarak Provinsi Sumatera Barat. Metamorfosa-Journal of Biological Sciences. 6 (1): 67-74. 